\title{
Wenlock and Pridoli (Silurian) crinoids from Saaremaa, western Estonia (Phylum Echinodermata)
}

\author{
William I. Ausich ${ }^{1}$, Mark A. Wilson ${ }^{2}$, and Olev Vinn ${ }^{3}$ \\ ${ }^{1}$ School of Earth Sciences, 155 South Oval Mall, The Ohio State University, Columbus 43210, USA; 〈ausich.1@ osu.edu〉 \\ ${ }^{2}$ Department of Geology, The College of Wooster, Wooster, Ohio 44691, USA; 〈mwilson@ wooster.edu〉 \\ ${ }^{3}$ Department of Geology, University of Tartu, Ravila 14 A, 50411 Tartu, Estonia; 〈olev.vinn@ut.ee〉
}

\begin{abstract}
Study of new collections of the Wenlock and Pridoli, Silurian, crinoids from Saaremaa, western Estonia, result in taxonomic revision, expanded ranges, and new taxa. Eucalyptocrinites regularis and Periechocrinus laevis are recognized outside of Sweden for the first time. Desmidocrinus laevigatus Ausich et al., 2012 is reassigned to Methabocrinus. Because the type species of Methabocrinus was previously known only from glacial sediments, the age and provenance of this genus are constrained for the first time. A new crotalocrinitid, Velocrinus coniculus new genus and species, is described. Although the Pridoli faunas of western Estonia contain only twelve species-level taxa assigned to nine genera, this fauna is one of the four richest Pridoli faunas known.
\end{abstract}

\section{Introduction}

Pridoli crinoids are poorly understood globally, with the richest fauna known from western Tennessee (USA). With the material reported by Ausich et al. (2012) and the new material reported here, the fauna from the Kaugatuma Formation (Saaremaa, western Estonia Islands) is among the four most diverse Pridoli faunas worldwide. Velocrinus coniculus n. gen. and sp. is described here, and Periechocrinus laevis? is reported from Estonia for the first time. Based on additional material and better-preserved specimens, Desmidocrinus laevigatus Ausich et al., 2012 is reassigned to Methabocrinus Jaekel, 1918. Previously, Methabocrinus was known exclusively from the holotype of the type species (M. erraticus Jaekel, 1918), which was collected from a glacial deposit in Germany. The age and provenance of this genus is constrained for the first time. In addition, new occurrences from the Wenlock of Saaremaa are also reported, including Calliocrinus sp. and Protaxocrinus? sp.; the most common Wenlockian Eucalyptocrinites from Saaremaa is recognized herein as E. regularis (Hisinger, 1840a).

\section{Saaremaa crinoid assemblages}

Wenlock.-The Wenlock crinoid fauna from Estonia has a low taxonomic richness with only ten species-level taxa assigned to seven genera (Table 1). However, Calliocrinus, Eucalyptocrinites, Periechocrinus, and Pisocrinus are among the most characteristic Wenlock crinoids both in Baltica (Gotland faunas) and North America. With the exception of Eucalyptocrinites, Wenlock crinoid specimens are quite rare in Estonia. Pisocrinus is only known from cores, where it is reasonably abundant.

Pridoli.-Similar to the Wenlock, Pridoli crinoids from Estonia are low in taxonomic richness: twelve species-level taxa assigned to nine genera. However, globally this is a substantial Pridoli fauna. The Estonian Pridoli fauna includes both genera that ranged up from the Wenlock and Ludlow (Calliocrinus, Cicerocrinus, Enallocrinus, Eucalyptocrinites, Myelodactylus, and Protaxocrinus) as well as genera with first occurrences in the Pridoli (Methabocrinus, Saaremaacrinus, and Velocrinus).

Globally, the Pridoli crinoid fauna from Saaremaa is among the four most diverse Pridoli faunas known. Determination of Pridoli crinoid faunas worldwide is problematic because these faunas are commonly reported from stratigraphic units listed as latest Silurian to earliest Devonian. Thus, the lack of precision from which faunas occur is a source of confusion. As presently understood, Pridoli crinoids are well documented from three paleocontinents, Baltica, Laurentia (Decatur Limestone, Tennessee; Henryhouse Formation, Oklahoma), and the Perunica microcontinent, Bohemia (Pozary Formation). The faunas from Estonia are known from both the Ohesaare Formation and the Kaugatuma Formation, the latter with the highest richness (Table 2).

The Estonian Pridoli fauna is comprised of both cosmopolitan and endemic genera and is more similar to Laurentian faunas than to those from Perunica, with which it shares no genera. The Baltic fauna (Estonia) shares the cosmopolitan genera Eucalyptocrinites and Myelodactylus with the Pridoli of Laurentia. Calliocrinus also occurs in the Wenlock to Ludlow of Baltica, the Wenlock of Laurentia, and the Lower Devonian of the Ural Mountains. Cicerocrinus is also known from the Ludlow of Avalonia, and Enallocrinus is also known from the Wenlock of Avalonia and the Wenlock and Ludlow of Baltica. Methabocrinus, Saaremaacrinus, and Velocrinus occur exclusively in the Pridoli of Baltica.

A reasonably large Pridoli fauna was reported from the Humevale Formation (eastern Australia) by Jell and Holloway (1983) and Jell (1999). However, similar to elsewhere in the world in late Silurian to early Devonian strata, chronostratigraphic 
Table 1. Wenlock and Pridoli crinoids from Saaremaa, Estonia.

\begin{tabular}{l} 
Pridoli \\
Ohesaare Formation \\
Cicerocrinus osiliensis (Jaekel, 1900) \\
Cicerocrinus scanicus (Jaekel, 1900) \\
Myelodactylus? sp. in Ausich et al., 2012 (columnals only) \\
Kaugatuma Formation (middle Äigu Beds) \\
Calliocrinus sedgwickianus Angelin, 1878 \\
Enallocrinus sp. in Ausich et al., 2012 (holdfasts and arms) \\
Eucalyptocrinites tumidus Ausich et al., 2012 \\
Eucalyptocrinites sp. 1 in Ausich et al., 2012 \\
Eucalyptocrinites sp. 2 in Ausich et al., 2012 \\
Methabocrinus laevigatus (Ausich et al., 2012) \\
Protaxocrinus? sp. herein \\
Saaremaacrinus estoniensis Ausich et al., 2012 \\
Velocrinus coniculus new gen. and sp. \\
Cladida indeterminate in Ausich et al., 2012 \\
Wenlock \\
Jaagarahu \\
Pisocrinus (Pisocrinus) pilula de Koninck, 1858 \\
Pisocrinus (Pisocrinus) trialobus Rozhnov and Männil in Rozhnov et al., 1989 \\
Pisocrinus (Granulosocrinus) lanceatus Rozhnov, 1981 \\
Jaani Formation, Ninase Member \\
Calliocrinus sp. in Ausich et al., 2012 and herein \\
Eucalyptocrinites regularis (Hisinger, 1840a) \\
Eucalyptocrinites sp. 1 in Ausich et al., 2012 \\
Eucalyptocrinites sp. in Ausich et al., 2012 \\
Perichocrinus laevis? Angelin, 1878 \\
Protaxocrinus salteri? in Ausich et al., 2012 \\
Jaani Formation, Mustjala Member \\
Eucalyptocrinites regularis (Hisinger, 1840a) \\
Jaani Formation, Member Unspecified \\
Periechocrinus longimanus? (Angelin, 1878) \\
Pisocrinus (Pocillocrinus) rubeli Rozhnov and Männil in Rozhnov et al., 1989 \\
\hline
\end{tabular}

Table 2. Systematic position of Pridoli crinoids from Saaremaa, Estonia.

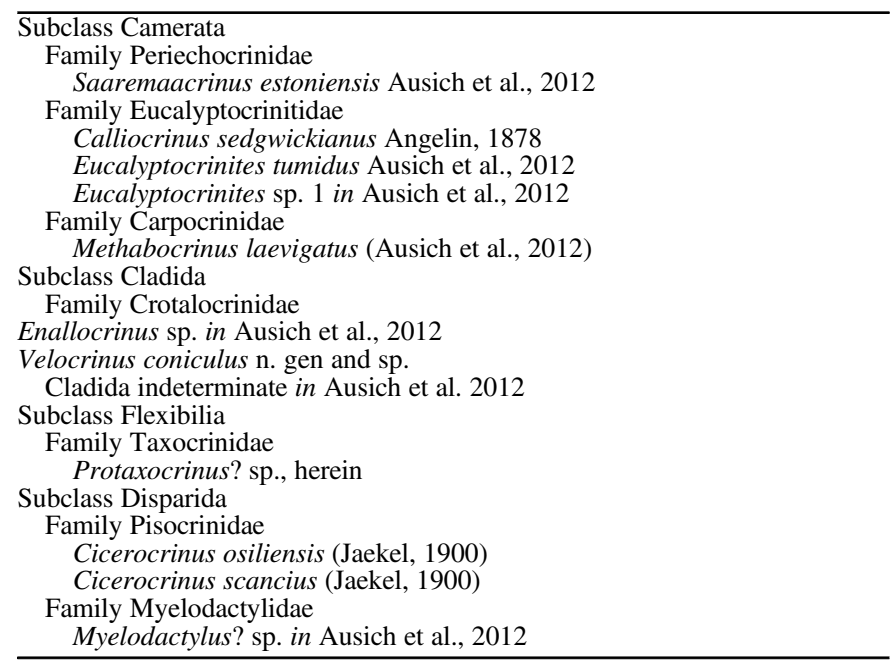

resolution in the Humevale Formation is insufficient to confidently recognize a Pridoli fauna (VandenBerg, personal communication, 2014).

\section{Stratigraphy and paleoenvironments}

The coastal cliffs and quarries of Saaremaa are the best natural exposures of Silurian strata in Estonia. Unlike the more thoroughly studied sections of Gotland, Sweden (which only include the latest Llandovery through Ludlow), Saaremaa geology includes Wenlock through Pridoli strata. Nestor and Einasto (1977), Raukas and Teedumäe (1997), Hints (2008), and Ausich et al. (2012) summarized the details of the Silurian stratigraphy and depositional setting of Estonia. Figure 1 illustrates the Silurian stratigraphic units of Estonia. The crinoids reported here are from the Mustjala and Ninase members of the Jaani Formation and the Kaugatuma Formation, which are time slices Sh2 and Pr1, respectively, of Cramer et al. (2010).

During the Silurian, Baltica was located in equatorial latitudes (Melchin et al., 2004). The western part of modern Estonia, including the islands, was covered by the epicontinental Baltic paleobasin. This basin was characterized by diverse faunas and a wide range of tropical shelf environments (Hints, 2008). The sedimentary facies of the Silurian of Estonia can be divided laterally into five facies belts or sedimentary environments along the reconstructed bathymetric profile (Nestor and Einasto, 1977): tidal flat/lagoonal, shoal, open shelf, basin slope, and a basin depression. The first three environments formed a carbonate platform. The latter two formed a deeper basin with fine-clastic deposits. The flat/lagoonal, shoal, open shelf, and basin slope sediments are represented in outcrops of western Estonia, but crinoids (both articulated and disarticulated remains) occur only in rocks from shoal, open shelf, and basin slope origin.

\section{Systematic paleontology}

Terminology follows Ubaghs (1978a) with modifications from Ausich et al. (1999), Sumrall and Waters (2012), and Kammer et al. (2013). Open nomenclature follows Matthews (1973) and Bengtson (1988). The scheme for defining relative proportions of the calyx follows Ubaghs (1978a, fig. 72). Geographic and stratigraphic details of Saaremaa Island localities are given in Ausich et al. (2012) and Appendix 1. All measurements are in millimeters, unless otherwise noted; and an asterisk indicates a crushed or broken specimen. Repositories are indicated as follows: TUG, University of Tartu; and TUT and TTÜGI, Institute of Geology, Tallinn University of Technology.

Class Crinoidea Miller, 1821

Subclass Camerata Wachsmuth and Springer, 1885

Order Monobathrida Moore and Laudon, 1943

Suborder Compsocrinina Ubaghs, 1978b

Superfamily Perichocrinoidea Bronn, 1849

Genus Periechocrinus Morris, 1843

Type species.-Periechocrinus costatus Austin and Austin, 1842.

Periechocrinus laevis? Angelin, 1878

Figure 2.3

1878 Periechocrinus laevis Angelin, p. 7, pl. 18, fig. 11.

1881 Periechocrinus minor Wachsmuth and Springer, p. 132 (306).

1943 Periechocrinites laevis; Bassler and Moodey, p. 599.

1983 Periechocrinus laevis; Franzén, p. 6.

2014 Periechocrinus laevis; Webster and Webster, p. 2056.

Remarks.-One poorly preserved crinoid calyx, assigned to P. laevis? Angelin, 1878, was collected from the Ninase Member of the Jaani Formation. The calyx has a high bowl shape and the fixed interrays have a biseries of interradial plates (Fig. 2.3), which is consistent with Periechocrinus. Unfortunately, poorly preserved plating exists around approximately one third of the 


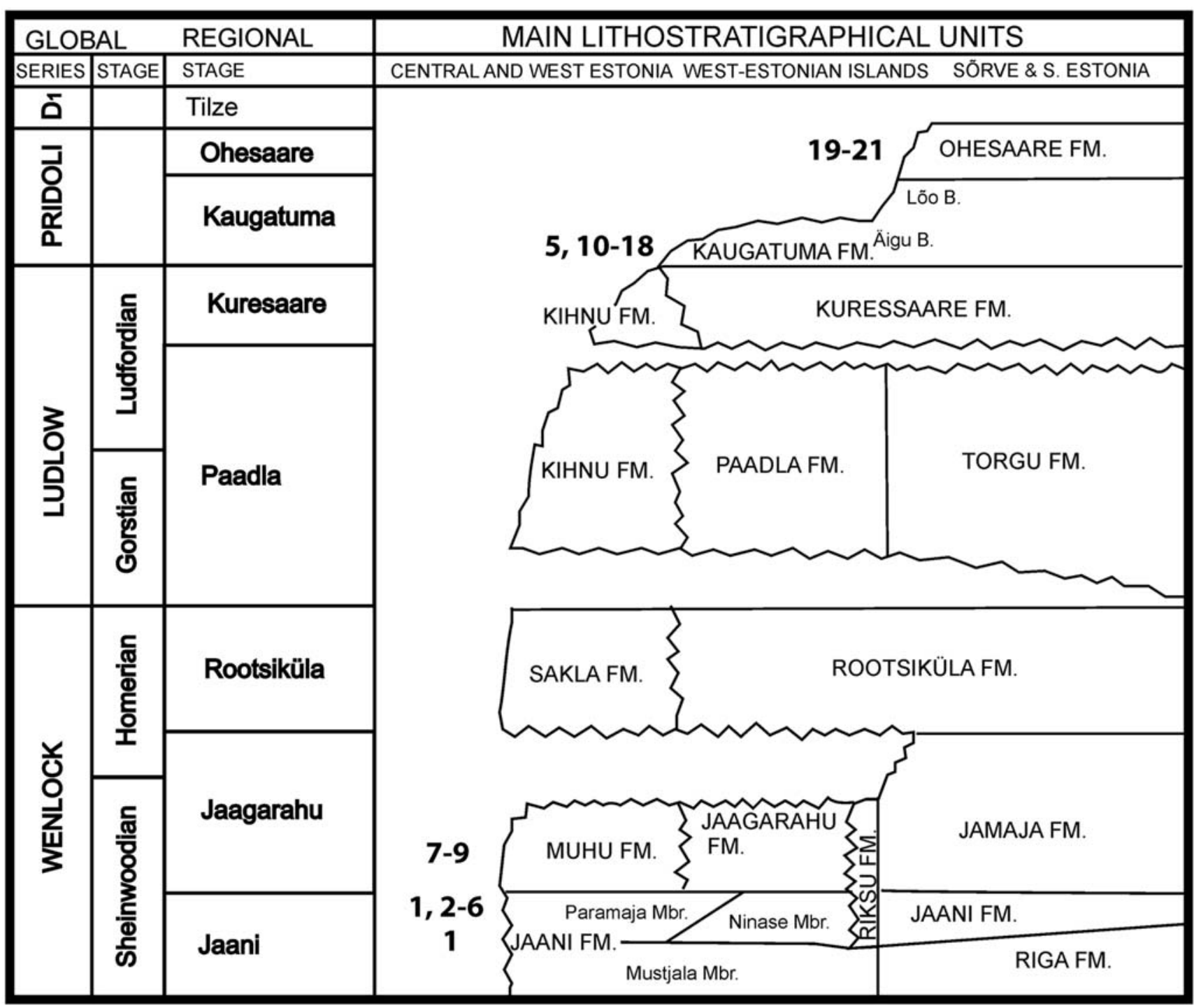

Figure 1. Silurian stratigraphy of Estonia. New fossil specimens are from the West-Estonian islands, the middle column of the chart of lithostratigraphic units (based on Hints, 2008). D1, Lower Devonian; O, Ordovician, O3, Upper Ordovician.

specimen, and the remainder of the calyx is preserved as an internal mold.

This new specimen is larger ( $25 \mathrm{~mm}$ high, $20 \mathrm{~mm}$ wide) than the specimens reported as $P$. longimanus (Angelin, 1878) by Ausich et al. (2012), and they also differ because the new specimen has median ray ridges, which at present is regarded a reliable species-level character among Periechocrinus species from Gotland. Franzén (1983) reported four Gotland specimens of Periechocrinus that have smooth plate sculpturing and median ray ridges (like the new specimen). Of these, $P$. annulatus (Angelin, 1878) and P. lindstromi Wachsmuth and Springer, 1881 have lower calyxes than TUG 1395-61. Periechocrinus scanicus Angelin, 1878 has more fixed brachials than the new specimen is interpreted to have, but the new Saaremaa specimen is very similar to $P$. laevis. Because TUG $1395-61$ is so poorly preserved, a tentative identification is appropriate; thus, we recognize this taxon as P. laevis?. Franzén (1983) was unable to determine the location of this species on Gotland, so its probable occurrence in the Wenlock of Estonia helps to define the stratigraphic range of this species.
Material.-TUG 1395-61.

Occurrence.-Ninase Member, Jaani Formation at Undva Cliff, Saaremaa Island, Estonia.

Suborder Glyptocrinina Moore, 1952

Superfamily Eucalyptocrinitoidea Roemer, 1855

Family Eucalyptocrinitidea Roemer, 1855

Genus Eucalyptocrinites Goldfuss, 1831

Eucalyptocrinites regularis (Hisinger, 1840a) Figure 2.9

1840a Actinocrinites regularis Hisinger, p. 6, pl. 39, fig. 6.

$1840 \mathrm{~b}$ Actinocrinites regularis; Hisinger, p. 45.

1848 Eucalyptocrinus regularis; Bronn, p. 474.

1851 Eucalyptocrinus regularis; Roemer in Bronn and Roemer, p. 260.

1852- Eucalyptocrinus regularis; Roemer in Bronn, 1854 p. 260. 

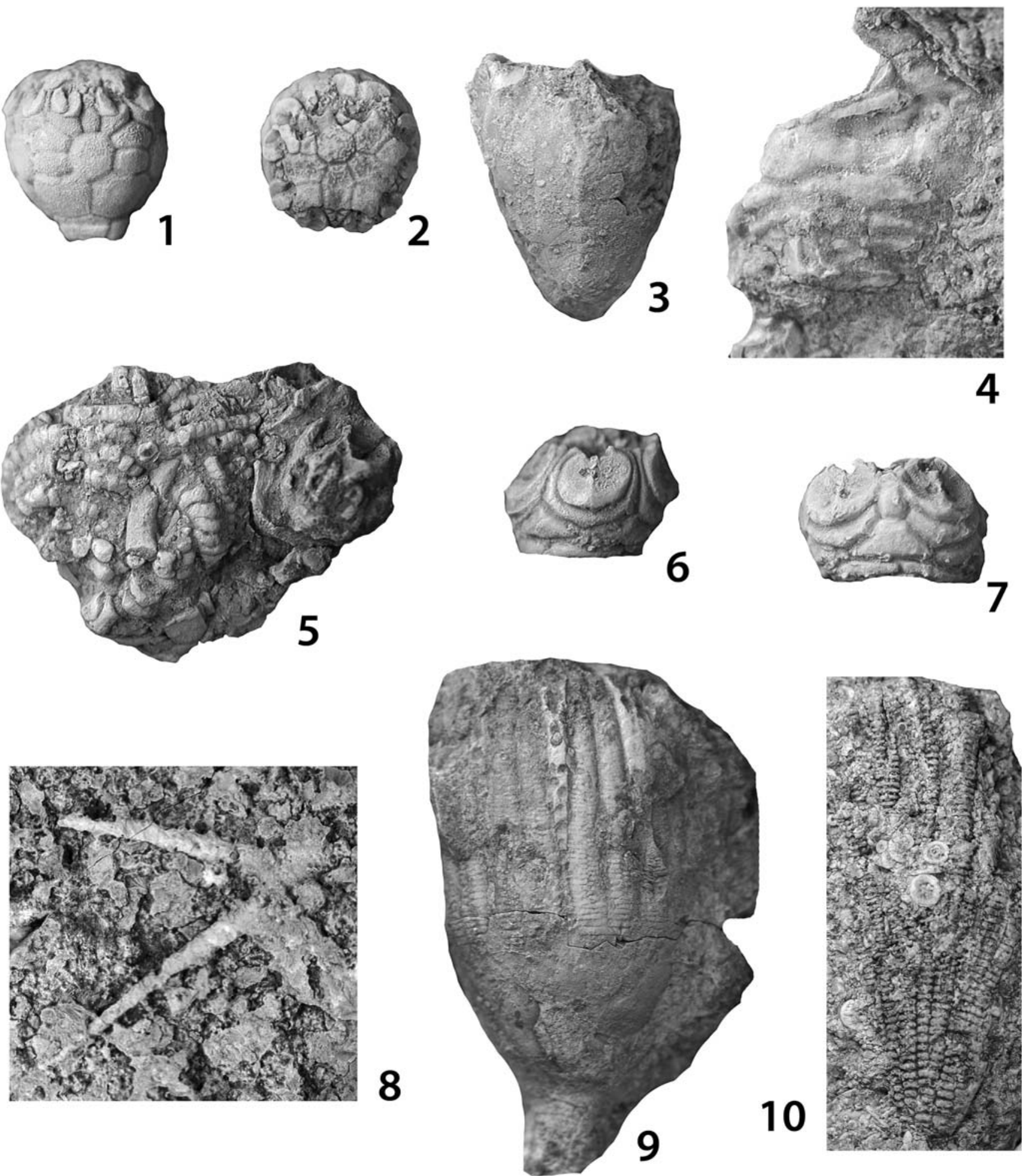

Figure 2. Estonian Silurian Crinoids. (1, 2) Methabocrinus laevigatus (Ausich, Wilson, and Vinn, 2012) TUG 1395-40, X2.5; 1, CD-interray view; (2) tegmen view. (3) Periechocrinus laevis? Angelin, 1878, lateral view, TUG 1395-61, X1.75. (4) Enallocrinus? sp., lateral view of a partial aboral cup, TUG 1395-44, X2.5. (5) Protaxocrinus? sp., oral view of a crown with infolded arms, TUG 1395-60, X2.5. (6, 7) Velocrinus coniculus, TUG 1395-42, X2.5; (6) E-ray lateral view; (7) CD-interray lateral view. (8) Calliocrinus sp., tegmen spine, TUG 1395-43, X1.5. (9) Eucalyptocrinites regularis (Hisinger, 1840), lateral view of crown, note Sedilichnus along partition plates, TUG 1395-46, X1.0. (10) Enallocrinus sp., aboral view of one isolated arm, TUG 1395-45, X1.0.

1862 Eucalyptocrinus regularis; Dujardin and Hupé, p. 116.1878

1868 Actinocrinus regularis; Bigsby, p. 196.

1876 Actinocrinus regularis; Quenstedt, p. 636, pl. 112, figs. $57,58$.
Hypanocrinus regularis; Angelin, p. 17, pl. 6, figs. 2-3c, pl. 24, figs. 11-11f, 20; pl. 29, figs. 35-64, 71.

1880 Hypanocrinus regularis; Zittel, p. 380, fig. 266.

1895 Hypanocrinus regularis; Zittel, p. 133, fig. 253. 
1900 Eucalyptocrinus regularis; Wachsmuth in Zittel, p. 148, fig. 251.

1943 Eucalyptocrinites regularis; Bassler and Moodey, p. 466.

1983 Eucalyptocrinites regularis; Franzén, p. 8.

2014 Eucalyptocrinites regularis; Webster and Webster, p. 1448.

Diagnosis.-Medium cone-shaped tegmen, smooth calyx plate sculpturing, base of calyx relatively narrow, basal plates not visible in side view, partition plates conspicuously widen distally.

Description.-Calyx medium size for genus; low cone. Calyx plate sculpturing smooth; median ray ridges.

Basal circlet covered. Radial circlet approximately $20 \%$ of calyx height; presumably five radial plates, pentagonal. Normal interrays in contact with tegmen partition plates; first interradial decagonal, higher than wide, larger than radial plate, much larger than first primibrachial. Second range with two plates that are sutured to the interradial tegmen partition plates. Posterior interray not exposed or indistinguishable from normal interrays (as in other species).

First primibrachials tetragonal, approximately as wide as high, approximately same size as primaxil. Second secundibrachial axillary in all rays, yielding four arms per ray. One fixed intrabrachial sutured distally with partition plate, approximately two times higher than wide.

Tegmen comprised of ten partition plates that extend to base of the anal tube and rise to full height of arms. Partition plates widen distally to three times proximal width; broad, deep centrally positioned groove along distal one third of partition plate (Fig. 1.9). Short anal tube extends above arms.

Free arms 20, atomous, probably pinnulate, first few tertibrachials fixed, cuneate uniserial through the first five tertibrachials, thereafter biserial. Arms reach to the distal extent of the partition plates.

Column unknown.

Material.-GIT 405-238, 1395-46 to \#1395-55, TUG 860-136, TUG 860-137, TUG 1395-10, TUG 1395-12 to TUG 1395-16.

Occurrence.-Eucalyptocrinites regularis was originally described from Gotland, Sweden, where it is currently recognized from the Högklint Formation (Wenlock) (Franzén, 1983). As listed above, this species is now recognized from Saaremaa, Estonia, from the Mustjala and Ninase Members of the Jaani Formation at Liiva Cliff, Suuriku Cliff, and Undva Cliff, Saaremaa Island, Estonia.

Remarks._As discussed in Ausich et al. (2012), Franzén (1983) listed three species of Eucalyptocrinites from Gotland with smooth calyx plating, basal plates not visible, and partition plates that conspicuously widen distally, including E. plebejus (Angelin, 1878), E. regularis (Hisinger, 1840), and E. rigens (Angelin, 1878). These three species are distinguished by the following (based both on specimens and on figures from Angelin, 1878): both E. plebejus and E. rigens have broadly truncate calyx bases from which a basal concavity begins, whereas $E$. regularis has a much narrower calyx base. The latter is consistent with specimen $1395-46$, our only complete crown, and with numerous calyxes that are preserved in isolation from the tegmen and arms. Therefore, we identify E. regularis from the Ninase Member, Jaani Formation (Wenlock) from Undva Cliff (TUG 1395-47 to TUG 1395-54). Further, we identify the following specimens that have less complete preservation as E. regularis: Mustjala Member, Jaani Formation, from Suuriku Cliff (TUG 1395-12); Ninase Member, Jaani Formation, from Suuriku Cliff (TUG 1395-14 and TUG 1395-55); Ninase Member, Jaani Formation, from Undva Cliff (TUG 1395-15, TUG 1395-16); and Ninase Member, Jaani Formation, from Panga Cliff (TUG 1395-13).

An interesting aspect of this species is that specimens have been heavily drilled. The trace fossil Sedilichnus Müller, 1977 occurs along the partition plates of E. regularis (Fig. 2.9).

Measurements.-TUG 1395-47: Crown height, $40 \mathrm{~mm}$; aboral cup height, $15 \mathrm{~mm}$; aboral cup maximum width, $21 \mathrm{~mm}$.

Genus Calliocrinus d'Orbigny, 1850

Type species.—Eugeniacrinites? costus Hisinger, 1837.

\section{Calliocrinus sp. \\ Figure 2.8}

Material.-TUG 1395-5 and TUG 1395-6 from Suuriku Cliff; new material is from Undva Cliff: TUG 1395-43.

Occurrence.-Calliocrinus sp. is recognized from the Ninase Member, Jaani Formation at Suuriku Cliff and Undva Cliff, Saaremaa Island, Estonia.

Remarks.-Ausich et al. (2012) reported large, isolated, bifurcating spine plates from the Ninase Member of the Jaani Formation at Suuriku Cliff and identified them as belonging to Calliocrinus sp. An additional specimen TUG 1395-43 is reported, herein, from the Ninase Member at Undva Cliff. This spine is approximately $40 \mathrm{~mm}$ long and approximately $30 \mathrm{~mm}$ wide at its widest breadth (Fig. 2.8).

Superfamily Carpocrinoidea de Koninck and Le Hon, 1854

Family Carpocrinidae de Koninck and Le Hon, 1854 Genus Methabocrinus Jaekel, 1918

Type species.-Methabocrinus erraticus Jaekel, 1918.

Occurrence.-It is unlikely that the original stratigraphic and geographic location of the type species will ever be known. Thus, the occurrence of M. laevigatus must represent this genus, which is Pridoli, Silurian; Estonia.

Remarks.-Ausich et al. (2012) described Desmidocrinus laevigatus from two calyxes (one significantly weathered), but neither specimen had a preserved tegmen. Placed in Desmidocrinus, this material was a somewhat unusual species for the genus with a reduced number of arms and reduced plating in the regular and CD interrays. However, with the newly discovered 
specimen TUG 1395-43, which preserves a nearly complete tegmen diagnostic of Methabocrinus, this species is transferred to Methabocrinus. It is a species with more plates in the regular and $\mathrm{CD}$ interrays than the type species, $M$. erraticus.

This is an especially significant discovery because Methabocrinus was previously known from a single specimen collected from glacial drift in Germany (Jaekel, 1918; Ubaghs, $1958,1978 b$ ), thus its age and provenance was speculative. Although the age of the type species may never be known, the genus can now be recognized with certainty from the Pridoli of Estonia.

Methabocrinus laevigatus (Ausich, Wilson, and Vinn, 2012) Figure 2.1, 2.2

2012 Desmidocrinus laevigatus Ausich, Wilson, and Vinn, p. 622 , fig. $5 \mathrm{G}, 5 \mathrm{H}$.

Diagnosis.-Methabocrinus with a more globe-shaped calyx in adults, basal plates equal in size, regular interray plating 1-1, concave; primary peristomial cover plates, broadly convex radially positioned tegmen plates.

Description.-Calyx medium in size for genus, low bowl to globe shape (Fig. 2.1); arms not grouped; calyx plates convex, finely and irregularly granulose sculpturing, plate sutures broadly impressed (Fig. 2.1).

Basal circlet visible in side view (Fig. 2.1), projects downward altering convex profile of remainder of calyx, approximately $18 \%$ of calyx height, shallow basal concavity; basal plates three, equal in size. Radial circlet averages $32 \%$ of calyx height, interrupted in posterior; radial plates five, hexagonal, approximately 1.4 times wider than high. Normal interrays in contact with tegmen, first interradial octagonal, approximately 1.1 times wider than high, smaller than radials and much larger than first primibrachials, extends from shoulders of radial plates to the lower part of the first secundibrachial; only one other interradial plate fixed in calyx resulting in 1-1 plating, although this series of plates articulated to one or two proximal plates of tegmen. Primanal hexagonal, approximately equal in height and width, same size as radial plates, and interrupts the radial circlet; plating in CD interray P-3-3-4; anitaxis of plates, anitaxial ridge absent; $\mathrm{CD}$ interray in contact with tegmen.

First primibrachial tetragonal, approximately 1.5 times wider than high, much smaller than radial plates and somewhat smaller than primaxil; second primibrachial axillary, pentagonal to heptagonal. First secundibrachial fixed, distal-most fixed brachial with narrow crenularium around margin of facet, adjacent first secundibrachials within a ray in contact medially. A single intrabrachial plate in center of ray sutured on upper shoulder of first secundibrachials and extending onto tegmen.

Tegmen with mouth subtegminal, five large primary peristomial cover plates with CD peristomial cover plate the largest occupying a central position and extending abaxially to the periproct (Fig. 2.2). Primary peristomial cover plates in regular interrays concave, extend to the arm openings, articulated to two smaller plates that are either articulated with the distal-most interradial plate or articulated with a second range of two small plates that in turn articulate with the distal- most interradial plate. A single, large, roughly diamond-shaped, broadly convex, radially positioned tegmen plate in each ray forms admedial frame around arm opening and articulates to a single intrabrachial plate.

Free arms 10, branch, brachials biserial; aborally very convex; arms branch on approximately ninth free brachial; pinnules and other aspects of free arms unknown.

Most proximal columnal circular, holomeric; lumen pentalobate. Narrow crenularium (30\% of columnal radius), areola wide (48\% of columnal radius), and lumen $22 \%$ of columnal radius. Other aspects of column unknown.

Material.-TUG 1395-1 (holotype), TUG 1395-2 (paratype), and the following additional specimens: TUG 1395-40 and TUG 1395-41.

Occurrence.-All specimens of this species are from the Middle Äigu Beds, Kaugatuma Formation (Pridoli), at Kaugatuma Cliff, Saaremaa Island, Estonia.

Remarks.-The two new specimens (TUG 1395-40 and TUG 1395-41) are both smaller than the previously known specimens, with TUG 1395-40 having a complete calyx and nearly complete tegmen. TUG $1395-40$ is not weathered, so plate sculpturing is well preserved. M. laevigatus differs from M. erraticus with more interradial plates fixed into the calyx in regular interrays, the $\mathrm{CD}$ interray, and in a medial intrabrachial position. Further, the topography of the tegmen differs. Methabocrinus erraticus has a prominent ridge on both the primary peristomial cover plates and the large radially positioned tegmen plates that together form concave niches into which the ten free arms were presumably placed. In contrast, these niches do not exist in M. laevigatus, with the primary peristomial cover plates concave and large radially positioned tegmen plates only broadly convex.

Subclass Cladida Moore and Laudon, 1943

Order Cyathocrinida Bather, 1899

Superfamily Gasterocomoidea Roemer, 1854

Family Crotalocrinitidae Bassler, 1938

Genus Enallocrinus d'Orbigny, 1850

Type species.—Apiocrinites scriptus Hisinger, 1828.

Enallocrinus sp.

Figure 2.4, 2.10

Occurrence.-Enallocrinus holdfasts are recognized from Gotland, Sweden, in the Hemse Beds (Gorstian, lower Ludlow; Franzén 1977) and the lower Klinteberg Formation (Homerian, Wenlock; Donovan et al., 2007). In Estonia, Enallocrinus holdfasts are from the Middle Äigu Beds, Kaugatuma Formation (Pridoli), at Kaugatuma Cliff, Saaremaa Island, Estonia.

Remarks.-Ausich et al. (2012) concluded that the abundant, large rhizoid holdfasts that characterize the Kaugatuma Cliff locality belonged to Enallocrinus sp. based on comparison to Gotland specimens discussed in Donovan et al. (2007). Herein, this assignment is corroborated further by new material from Kaugatuma Cliff. The calcite of the Saaremaa Enallocrinus 
holdfasts varies in color from dark gray to white. On one limestone slab a dark gray holdfast occurred adjacent a light to dark gray partial set of articulated arms approximately $80 \mathrm{~cm}$ long (TUG 1395-45) (Fig. 2.10). This partial arm set begins proximally with three, laterally fused arms, which divide into five laterally fused arms. The fused brachials have a normal shape (unlike Crotalocrinites Austin and Austin, 1843). The brachials are uniserial, and each brachial has a prominent, elongate node (Fig. 2.10). They are much wider than high and vary from tetragonal to hexagonal in shape. The arms bifurcate irregularly a few additional times and remain laterally fused for a total of approximately $50 \mathrm{~mm}$, after which they become free with uniserial brachials that may divide further. Although not identical, this partial arm set is quite similar to Enallocrinus arms illustrated in Angelin (1878, e.g., pl. 15, figs. 1, 1a, 3).

More speculative but supporting the occurrence of Enallocrinus is a small fragment of a crinoid calyx (GUT 1395-44) that is tentatively identified as Enallocrinus sp. This fragment is interpreted to be primarily the most proximal fixed brachials of an Enallocrinus calyx (Fig. 2.4). Some species of Enallocrinus have very elongate, very nodose fixed primibrachials and secundibrachials, similar to this specimen. However, the exact interpretation of this specimen must be tentative because it is such a small fragment.

In summary, the Enallocrinus interpretation by Donovan et al. (2007) of the distinctive Gotland rhizoid holdfasts is supported by new material from the Kaugatuma Formation of Saaremaa.

Material.-TUG 1395-38 and TUG 1395-39 were previously deposited by Ausich et al. (2012). Additional specimens include TUG 1395-45 and TUG 1395-44 (which is questionably assigned to this taxon).

\section{Genus Velocrinus new genus}

Type species.-Velocrinus coniculus n. gen. and sp., by monotypy.

Diagnosis.-Crotalocrinitid with a calyx cone shaped, lacking stereomic overgrowths, comprised of relatively large plates; infrabasals not fused, visible in lateral view; two anal plates; primaxil minute, not visible in lateral view; fixed brachials present; free arms not laterally linked; anus on tegmen; (nature of tegmen plating unknown).

Etymology.-From velo (L., n.; cover), which refers to the diminutive primibrachials not visible in lateral view.

Occurrence.-Pridoli, Late Silurian, Estonia.

Remarks.-Velocrinus $\mathrm{n}$. gen. is recognized as belonging to the Crotalocrinitidae because of the plating in the CD interray, fixed brachial plates, and axial canal within radial plates and brachial plates. However, this crinoid differs from other crotalocrinitids with a combination of having fixed brachials, fixed arms not sutured or linked, primaxial minute and not visible in lateral view, five infrabasal plates that are visible in lateral view, and two anal plates in the cup. With a cone-shaped calyx, Velocrinus is most similar to Enallocrinus, Pleuroptyx, and Syndetocrinus. The latter three genera have fixed brachials through the tertibrachials, the primaxil visible in lateral view, and one anal plate in the cup. Enallocrinus has a minute primaxil, whereas Syndetocrinus has a large primaxil. In contrast, Velocrinus has only fixed primibrachials, a minute primaxil that is not visible in lateral view, and two anal plates in the cup.

\section{Velocrinus coniculus new genus and species} Figure 2.6, 2.7

Diagnosis.-Velocrinid with a calyx cone-shaped, lacking stereomic overgrowths, comprised of relatively large plates; infrabasals not fused, visible in lateral view; primaxil minute, not visible in lateral view; fixed brachials present; free arms not laterally linked; anus on tegmen (nature of tegmen plating unknown).

Etymology.-From coniculus (L.; cone-like, conical), which refers to the cone-shaped calyx.

Description.-Aboral cup small, low globe shape, width to height ratio approximately 1.75 , plates very gently convex, irregular sculpturing, sutures deeply impressed. Infrabasals probably five and equal in size, 5.6 times wider than high, infrabasal circlet approximately $10 \%$ of aboral cup height, base truncate (Fig. 2.6). Basals five, triangular, 2.1 times wider than high, smaller than radials; basal circlet approximately $30 \%$ of aboral cup height. Radials five, broadly pentagonal except $\mathrm{C}$ and $\mathrm{D}$ radials that articulate with small CD interray plates, approximately 1.1 times wider than as high; radial circlet approximately $60 \%$ of aboral cup height (Fig. 3). Radial facets large, angustary, horseshoe shape, declivate, occupy approximately $87 \%$ of distal radial plate width (Fig. 2.6). Dumbbell-shaped axial canal; ovate adoral groove partially enclosed distally by distal extensions of the radial plate curving adaxially and partially divided by primaxil that divides the axial canal; radial facet topography unknown.

Two anal plates in cup; arranged 1-1, interpreted as anal X and right tube plate (Fig. 2.7). Anal $\mathrm{X}$ in contact with $\mathrm{CD}$ basal beneath, hexagonal, nodose, extends distally to middle height of radial facet. Right tube plate pentagonal, directly above anal X in contact distally with small plates that form margin of periproct. Anal opening at margin of tegmen; other details of tegmen unknown.

Arms known only from first and second (axillary) primibrachials. First primibrachial facet large, horseshoe-shaped, 1.3 times wider than high. Primaxil diminutive, hexagonal, 2.1 times wider than high, not visible on aboral side of arm, forms a narrow partition plate dividing the dumbbell-shaped axial canal on the radial facet. Facet onto which the first secundibrachials articulate is primarily that of the first primibrachial (only articulating medially with the diminutive primaxil). First primibrachial facet topography a series of concentrically aligned nodes from the facet margin toward the axial canal.

Column unknown.

Holotype.-TUG 1395-42.

Occurrence.-Middle Äigu Beds, Kaugatuma Formation (Pridoli) at Kaugatuma Cliff, Saaremaa Island, Estonia. 


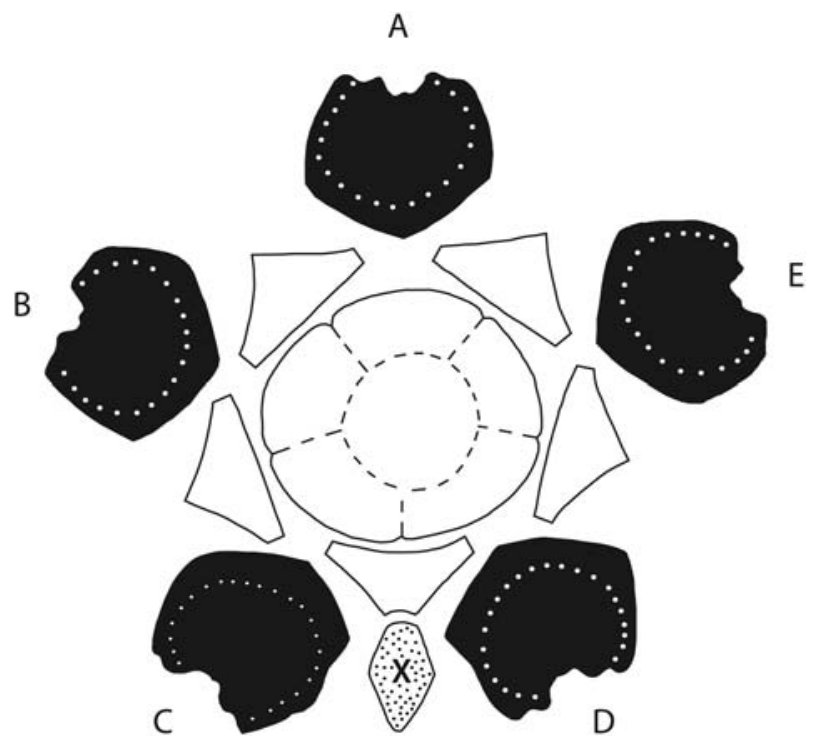

Figure 3. Plate diagram of Velocrinus coniculus n. gen. and sp. Black, radial plates; stippled pattern, anal X; and dotted line, limits of radial facet; dashed line, poorly visible or inferred plate sutures.

Measurements.-Infrabasal plate height, 2.0; width, 11.2. Basal plate height, 6.1; width 12.8. Radial plate height, 12.4; width 14.1. First primibrachial facet height, 8.4, width, 10.8 .

Subclass Flexibilia von Zittel, 1895

Order Taxocrinida Springer, 1913

Superfamily Taxocrinoidea Angelin, 1878

Family Taxocrinidae Angelin, 1878

Genus Protaxocrinus Springer, 1906

Type species.-Taxocrinus ovalis Angelin, 1878; by subsequent designation; Gotland, Sweden; Wenlock, Silurian.

\section{Protaxocrinus? sp.}

Figure 2.5

\section{Material.-TUG 1395-60.}

Occurrence.—Middle Äigu Beds, Kaugatuma Formation (Pridoli) at Kaugatuma Cliff, Saaremaa Island, Estonia.

Remarks.-An incomplete and partially disarticulated crown (mostly arms) is assigned to Protaxocrinus? sp. It is small (less than $20 \mathrm{~mm}$ in diameter) and may represent a juvenile. Both the abaxially incurved arms and patelloid processes on some proximal brachials indicated that this specimen is a flexible and potentially a taxocrinid (Fig. 2.5). What is known of its morphology is consistent with other Silurian examples of Protaxocrinus.

\section{Crinoidea incertae sedis}

Remarks.-Several (TUG 1395-64 to TUG 1395-70) terminal holdfasts with branching pseudocirri occur in the Middle Äigu Beds, Kaugatuma Formation (Pridoli) at Kaugatuma Cliff, Saaremaa Island, Estonia.

\section{Acknowledgments}

We thank A. Bancroft, R. Ekka, J. Novak, M. Peter, J. Thompson, and I. Vinn for help with field work. The reviews by D.L. Meyer and G.D. Sevastopulo significantly improved an earlier draft of this manuscript. Support for this research was from the National Geographic Society (NGS 60031112), The College of Wooster, The Ohio State University, and the University of Tartu. O.V. acknowledges Estonian Science Foundation grant ETF9064, Estonian Research Council grant IUT20-34 and the targetfinanced project (from the Estonian Ministry of Education and Science) SF0180051s08 for financial support.

\section{References}

Angelin, N.P., 1878, Iconographia Crinoideorum, stratis Sueciae Siluricis fossilium: Samson and Wallin, Holmiae, $62 \mathrm{p}$.

Ausich, W.I., Brett, C.E., Hess, H., and Simms, M.J., 1999, Crinoid form and function, in Hess, H., Ausich, W.I., Brett, C.E., and Simms, M.J., Fossil Crinoids: Cambridge, Cambridge University Press, p. 3-30.

Ausich, W.I., Wilson, M.A., and Vinn, O., 2012, Crinoids from the Silurian of Western Estonia: Acta Palaeontologica Polonica, v. 57, p. 613-631.

Austin, T., and Austin, T., 1842, XVIII, - Proposed arrangement of the Echinodermata, particularly as regards the Crinoidea, and a subdivision of the Class Adelostella (Echinidae): Annals and Magazine of Natural History, ser. 1 , v. 10 , no. 63 , p. 106-113.

Austin, T., and Austin, T., 1843, XXXIII, - Description of several new genera and species of Crinoidea: Annals and Magazine of Natural History, ser. 1, v. 11 , no. 69 , p. $195-207$.

Bassler, R.S., 1938, Pelmatozoa Palaeozoica, in Quenstedt, W., ed., Fossilium Catalogus, I: Animalia, Part 83, W. Junk, s'Gravenhage, 194 p.

Bassler, R.S., and Moodey, M.W., 1943, Bibliographic and faunal index of Paleozoic pelmatozoan echinoderms: Geological Society of America Special Paper, v. 45, $734 \mathrm{p}$.

Bather, F.A., 1899, A phylogenetic classification of the Pelmatozoa: British Association for the Advancement of Science (1898), p. 916-923.

Bengtson, P., 1988, Open nomenclature: Palaeontology, v. 31, p. 223-227.

Bigsby, J.J., 1868, Thesaurus Siluricus; the flora and fauna of the Silurian period. With Addenda (from recent acquisitions): London, J. Van Voorst, p. I-LII $+1-214$.

Bronn, H.G., 1848-49, Index palaeontologicus, unter Mitwirking der Herren Prof. H. R. Göppert und H. von Meyer: Handbuch einer Geschichte der Nature 5, Abt. v. 1, (1, 2), pt. 3, A. Nomenclator Palaeontologicus; A-M, p. $1-775 ; \mathrm{N}-\mathrm{Z}$, p. $776-1381$, Stuttgart.

Bronn, H.G., and Roemer, F., (C.F.), 1851-56, Lethaea Geognostica oder Abbildung und Beschreibung der für die Gebirgs-Formationen bezeichnendsten Versteinerungen. Dritte stark vermehrte Auflage bearbeitet von $\mathrm{H}$. G. Bronn and F. Roemer, Erster Band. 1. Übersichten, I. Theil. Systematische Übersicht der Fossilien; Schlüssel-Tabellen; Register, von H. G. Bronn. 2. Palaeo-Lethaea. II. Theil. Kohlen-Periode (Silur-, Devon-, Kohlen-, und Zechstein-Formation), von F. Roemer, 788 p., Zweiter Band (1851-52). 3. Meso-Lethaea. III. Theil, Trias-Periode; IV. Theil, Oolithen-Periode; V. Theil, Kreide-Periode. Stuttgart, E Schweizerbart, 412 p., Atlas, $124 \mathrm{pl}$.

Cramer, B.D., Brett, C.E., Melchin, M.J., Männik, P., Kleffner, M.A., McLaughlin, P.I., Loydell, D.K., Munnecke, A., Jeppsson, L., Corradini, C., Brunton, F.R., and Saltzman, M.R., 2010, Revised correlation of Silurian provincial series of North America with global and regional chronostratigraphic units and $\delta^{13} \mathrm{C}_{\text {carb }}$ chemostratigraphy: Lethaia, v. 44, p. 185-202, doi: 10.1111/j.1502-3931.2010.00234.x.

Donovan, S.K., Harper, D.A.T., and Håkansson, E., 2007, The root of the problem: palaeoecology of distinctive crinoid attachment structures from the Silurian (Wenlock) of Gotland: Lethaia, v. 40, p. 313-320, doi: 10.1111/ j.1502-3931.2007.00030.x.

Dujardin, F., and Hupé, L.-H., 1862, Histoire Naturelle des Zoophytes, Échinodermes: Library Encyclopédique, Paris, de Roret, Roret, 8 vols, 628 p.

Franzén, C., 1977, Crinoid holdfasts from the Silurian of Gotland: Lethaia, v. 10, p. 219-234, doi: 10.1111/j.1502-3931.1977.tb00617.x.

Franzén, C., 1983, Ecology and taxonomy of Silurian crinoids from Gotland: Acta Universitatis Upsaliensis, Abstracts of Uppsala Dissertations from the Faculty of Science, v. 665, 31 p.

Goldfuss, G.A., 1826-44, Petrefacta Germaniae, tam ea, Quae in Museo Universitatis Regiae Borussicae Fridericiae Wilhelmiae Rhenanea, serventur, quam alia quaecunque in Museis Hoeninghusiano Muensteriano aliisque, extant, iconibus et descriptions illustrata. - Abbildungen und 
Beschreibungen der Petrefacten Deutschlands und der Angränzende Länder, unter Mitwirkung des Hern Grafen Georg zu Münster, herausgegeben von August Goldfuss. v. 1 (1826-1833), Divisio prima. Zoophytorum reliquiae, p. 1-114; Divisio secunda. Radiariorum reliquiae, $\mathrm{p}$. 115-221 [Echinodermata]; Divisio tertia. Annulatorium reliquiae, p. 222-242; v. 2 (1834-40), Divisio quarta. Molluscorum acephalicorum reliquiae. I. Bivalvia, p. 65-286; II. Brachiopoda, p. 287-303; III (1841-44), Divisio quinta. Molluscorum gasteropodum reliquiae, p. 1-121, atlas of plates, 1-199, Düsseldorf, Arnz \& Co., v. 1, p. 1-76 (1826); p. 77164 (1829); p. 165-240 (1831); p. 241-252 (1833); v. 2, p. 1-68 (1833); p. 69-140 (1836); p. 141-224 (1837); p. 225-312 (1840); v. 3, p. 1-128 (1844).

Hints, O., 2008, The Silurian System in Estonia, in Hints, O., Ainsaar, L., Männik, P., and Meidla, T., eds., The Seventh Baltic Stratigraphical Conference: Abstracts and Field Guide, Geological Society of Estonia, $46 \mathrm{p}$.

Hisinger, W., 1828, Anteckningar i Physik och Geognosie under resor uti Sverige och Norrie: Stockholm, $260 \mathrm{p}$.

Hisinger, W., 1840a, Lethaea Suecica, seu petrificata Sueciae, iconibus et characteribus illustrata. Supplementum secundum, p. 1-11, pl. 38, Holmiae, D. A. Norstedt et filii.

Hisinger, W., 1840b, Anteckinger i Physik och Geognosie under resor uti Sverige och Norrige, Sjunde Haflet, Upsala, p. 15, 45, 64, 65, 72.

Jaekel, O., 1900, Über einen neuen Pentacrinodeen-Typus aus dem Obersilur: Zeitschrift der Deutschen Geologishen Gesellschaft, Jahrgang, v. 1900, p. 480-487.

Jaekel, O., 1918, Phylogenie und System der Pelmatozoen: Paläeontologische Zeitschrift, v. 3, no. 1, 128 p.

Jell, P.A., 1999, Silurian and Devonian crinoids from central Victoria: Memoirs of the Queensland Museum, v. 43, 114 p

Jell, P.A., and Hollway, D.J., 1983, Devonian and ?Late Silurian Palaeontology of the Winneke Reservoir site, Christmas Hills, Victoria: Proceedings of the Royal Society of Victoria, v. 95, p. 1-21.

Kammer, T.W., Sumrall, C.D., Zamora, S., Ausich, W.I., and Deline, B., 2013 , Oral region homologies in Paleozoic crinoids and other plesiomorphic pentaradial echinoderms: PLoS-ONE, v. 8, no. 11, 16 p. doi: 10.1371/ journal.pone.0077989.

Koninck, L.G. de., 1858, Sur quelques Crinoïdés Paleozoiques nouveaux de l'Angleterre et de l'Ecosse: Bulletin de la Académie Royale des Science, des Lettres et des Beau-Arts de Belgique ser. v. 24, p. 93-108.

Koninck, L.G. de., and Le Hon, H., 1854, Recherches sue les Crinoïdés du terrain Carbonifère de la Belgique: Académie Royale de Belgique, Mémoires, v. 38, $214 \mathrm{p}$

Matthews, S.C., 1973, Notes on open nomenclature and on synonymy lists: Palaeontology, v. 16, p. 713-719.

Melchin, M.J., Cooper, R.A., and Sadler, P.M., 2004, The Silurian Period, in Gradstein, F.M., Ogg, J.G., and Smith, A.G., eds., A Geologic Time Scale 2004; Cambridge, Cambridge University Press, p. 188-201.

Miller, J.S., 1821, A Natural History of the Crinoidea, or Lily-shaped Animals; with observations on the genera, Asteria, Euryale, Comatula and Marsupites: Bristol, England, C. Frost, $150 \mathrm{p}$.

Moore, R.C., 1952, Crinoids, in Moore, R.C., Lalicker, C.G., and Fischer, A.G., eds., Invertebrate Fossils: New York, McGraw-Hill Book Company, Inc., p. 604-652.

Moore, R.C., and Laudon, L.R., 1943, Evolution and classification of Paleozoic crinoids: Geological Society of America Special Paper, v. 46, 151 p.

Morris, J., 1843, A catalogue of British fossils, comprising all the genera and species hitherto described; with reference to their geological distribution and to the localities in which they have been found: London, John Van Voorst, 1st ed., $222 \mathrm{p}$.

Müller, A.H., 1977, Zur Ichnologie der subherzynen Oberkreide (Campan): Zeitschrift fur Geologishce Wissenschaften, v. 5, p. 881-897.

Nestor, H., and Einasto, R., 1977, Model of facies and sedimentology for Paleobaltic epicontinental basin, in Kaljo, D.L., ed., Facies and Fauna Silurian of Baltica: Tallinn, Institute of Geology AN ESSR, p. 89-121.

Orbigny, A.D.d', 1850-1852, Prodrome du paléontologie stratigraphique universelle des animaux mollusques et rayonnés faisant suite au cours élémentaire de paléontologie et de géologie stratigraphique: Victor Masson, Paris v 1 (1849 [1850]), p. $1-392$; v. 2 (1850 [1852]), p. 1-427; v. 3 (1852), p. $1-196$, + table alphabetique et synonymique des genres et des espèces, $189 \mathrm{p}$.

Quenstedt, F.A., 1874-76, Petrefactenkunde Deutschlands, Erst Abtheilung, Vierter (4) Band, Echinodermen (Asteriden und Encriniden). p. 1-742 (1876); Atlas zu den Echiniden, pl. 62-89 (1874); Atlas zu den Asteriden und Encriniden, pl. 90-114 (1876), Leipzig, 724 p.

Raukas, A., and Teedumäe, A., 1997, Geology and Mineral Resources of Estonia: Tallinn, Estonian Academy Publishers, $436 \mathrm{p}$

Roemer, C. F., 1851-56, Erste Periode, Kohlen-Gebirge, in Bronn, H.G., ed., Lethaea Geognostica: Stuttgart, 3rd edition, 2. E. Schweizerbart, 788 p.

Rozhnov, S.V., 1981, The crinoid Superfamily Pisocrinacea: Akademiya Nauk SSSR, Trudy Paleontologischeskogo Instituto, v. 192, p. 1-127.
Rozhnov, S.V., Männil, R., and Nestor, H., 1989, Pisocrinid crinoids from the Lower Silurian of the East Baltic, in D. L. Kaljo, ed., Problemy izučeniâ iskopaemyh I sovremennyh iglokož: SSR Tallinn, Academiâ Nauk Estonskog, p. 73-80.

Springer, F., 1906, Discovery of the disk of Onychocrinus and further remarks on the Crinoidea Flexibilia: Journal of Geology, v. 14, p. 467-523.

Springer, F., 1913, Crinoidea, in von Zittel, K.A., ed. Text-book of Palaeontology (translated and edited by C. R. Eastman): London, Macmillan \& Co., Ltd., 2nd edition, p. 173-243.

Sumrall, C.D., and Waters, J.A., 2012, Universal elemental homology in glyptocystitoids, hemicosmitoids, coronoids, and blastoids: steps toward echinoderm phylogenetic reconstruction in derived Blastozoa: Journal of Paleontology, v. 86, p. 956-972, doi: 10.1666/12-029R.1.

Ubaghs, G., 1958, Morphologie et position systématique de Methabocrinus erraticus Jaekel (Crinoidea Camerata): Paläontologische Zeitschrift, v. 32, p. 52-62.

Ubaghs, G., 1978a, Skeletal morphology of fossil crinoids, in Moore, R.C., and Teichert, K., eds., Treatise on Invertebrate Paleontology, Echinodermata, Pt. T(2): Boulder and Lawrence, Geological Society of America and University of Kansas Press, p. T58-T216.

Ubaghs, G., 1978b, Camerata, in Moore, R.C., and Teichert, K., eds., Treatise on Invertebrate Paleontology, Echinodermata, Pt. T(2): Boulder and Lawrence, Geological Society of America and University of Kansas Press, p. T408-T518.

Wachsmuth, C., and Springer, F., 1880-1886, Revision of the Palaeocrinoidea: Proceedings of the Academy of Natural Sciences of Philadelphia Pt. I. The families Ichthyocrinidae and Cyathocrinidae (1880), p. 226-378, pl. 15-17 (separate repaged p. 1-153, pl. 1-3). Pt. II. Family Sphaeroidocrinidae, with the sub-families Platycrinidae, Rhodocrinidae, and Actinocrinidae (1881), p. 177-411, pl. 17-19 (separate repaged, p. 1-237, pl. 17-19). Pt. III, Sec. 1. Discussion of the classification and relations of the brachiate crinoids, and conclusion of the generic descriptions (1885), p. 225-364, pl. 4-9 (separate repaged, 1-138, pl. 4-9). Pt. III, Sec. 2. Discussion of the classification and relations of the brachiate crinoids, and conclusion of the generic descriptions (1886), p. 64-226 (separate repaged to continue with section 1, 139-302).

Webster, G.D., and Webster, D.W. 2014, Bibliography and index of Paleozoic crinoids, coronates, and hemistreptocrinoids, 1758 - 2012. [http://crinoids. azurewebsites.net/] of America Special Paper, v. 363 http://crinoid. gsajournals.org/crinoidmod

von Zittel, K.A., 1876-80, Handbuch der Palaeontologie, v. 1, Palaeozoologie. München, Leipzig, R. Oldenbourg, (1879), no. 1, p. 1-765, (Echinoderms, p. 308-560).

von Zittel, K.A., 1895, Grundzüge der Palaeontologie (Palaeozoologie): München, R. Oldenbourg, 1st edition, $971 \mathrm{p}$.

von Zittel, K. A., 1896-1900, Text-book of Palaeontology, London, MacMillan \& Co., v. 1, 706 p.

\section{Appendix 1. Locality details. \\ Saaremaa Island}

Kaugatuma cliff ( $2.5 \mathrm{~m}$ high) is situated on the western coast of the Sorrve Peninsula, some kilometers south from its neck and about $100 \mathrm{~m}$ from the sea $\left(58^{\circ} 7^{\prime} 22^{\prime \prime} \mathrm{N}, 22^{\circ} 11^{\prime} 36^{\prime \prime} \mathrm{E}\right)$. Rocks (Kaugatuma Stage, Äigu Beds) of two different facies types in the regressive succession can be seen. The lower $0.5+\mathrm{m}$ of the section contains greenish-grey nodular argillaceous wackestone of open shelf origin. Skeletal debris consists mostly of echinoderm and brachiopod fragments (Hints, 2008). This layer is very rich in large crinoid holdfasts, some in life position. The upper $1.5+\mathrm{m}$ contains yellow-grey, coarse-grained, wavybedded crinoidal limestone of forereef origin (Hints, 2008).

Kuriku cliff (58 $\left.38^{\circ} 10.1514 " 22^{\circ} 0^{\prime} 46.224^{\prime \prime}\right)$ is located on the western shore of Tagalaht Bay a few hundred meters east of the Suuriku cliff. The outcrop is a 2-3 meters high section of Ninase Member of Jaani Formation. The upper part of the section is characterized by dolomitic boundstones with marlstone interbeds and cavernous dolomites (Hints, 2008). Small bioherms occur in the middle part of the section containing numerous bryozoans (O.V. personal communication.). Dolomitized crinoidal limestones and coarse-grained skeletal grainstones occur in the lower part of the section (Hints, 2008). The 
crinoid fossils are more common in the lower part of the section (O.V. personal communication). Most common fossils at the Kuriku cliff are tabulate corals, rugose corals and bryozoans (Hints, 2008).

Suuriku cliff is located in the northeastern coast of the Tagamõisa Peninsula in Saaremaa $\left(58^{\circ} 30^{\prime} 26^{\prime \prime} \mathrm{N}, 22^{\circ} 0^{\prime} 6^{\prime \prime} \mathrm{E}\right)$. The outcrop is $1.6 \mathrm{~km}$ long and up to $8 \mathrm{~m}$ high. In this locality the Mustjala and Ninase members of the Jaani Stage (Sheinwoodian, Wenlock) are exposed. Coarse-grained skeletal grainstones with interlayers of marlstones of the Ninase Member form the main, upper part of the section. The rock is mainly composed of pelmatozoans fragments. Brachiopods and gastropods are abundant, rugose corals are less common. Bioherms with abundant bryozoans (Ceramopora, Lioclema) occur in the middle part of the Ninase Member (Hints, 2008).
Clayey interlayers of Ninase Member contain relatively abundant remains of crinoid calyxes, some well preserved and retaining columnals (Olev Vinn personal communication) The lower part of the Suuriku section consists of marlstones of the Mustjala Member (Hints, 2008).

The Undva cliff is situated in the northern end of the Tagamõisa Peninsula, a few kilometers north from the Suuriku cliff $\left(58^{\circ} 31^{\prime} 1^{\prime \prime} \mathrm{N}, 21^{\circ} 55^{\prime} 7^{\prime \prime} \mathrm{E}\right)$. The cliff is about $350 \mathrm{~m}$ long and up to $2.5 \mathrm{~m}$ high, and the Mustjala and Ninase members of the Jaani Stage (Sheinwoodian, Wenlock) are exposed. The $1.5 \mathrm{~m}$ thick Ninase member consists of coarse-grained skeletal grainstones with interlayers of marlstone (Hints, 2008). Fragments of crinoid calyxes are common in the grainstones of the Ninase Member.

Accepted 2 April 2014 